UDC 821.161.1-31.09 Platonov A. https://doi.org/10.18485/ms_zmss.2021.100.39

\author{
Луиджи Магаротто \\ Венецианский Университет «Ка Фоскари» \\ mf11@unive.it \\ Luigi Magarotto \\ Venice University "Ca' Foscari" \\ mf11@unive.it
}

\title{
ТРАГИЧЕСКИЕ РЕШЕНИЯ В РОМАНЕ ЧЕВЕНГУР АНДРЕЯ ПЛАТОНОВА
}

\section{TRAGIC SOLUTIONS IN THE NOVEL CHEVENGUR BY ANDREY PLATONOV}

Автор анализирует основные темы, которые образуют структуру романа Чевенгур Андрея Платонова. Прежде всего он останавливается на перенасыщенной различными приемами и фрагментированной манере изложения писателя, которая приводит в замешательство читателя. Затем исследуется влияние теории о воскрешении мертвых, разработанной Николаем Федоровым. Далее автор показывает, что отсутствие женщин в Чевенгуре неизбежно приводит мужское население к проявлениям гомосексуальности. Коммунизм, созданный в Чевенгуре, кажется, руководствуется скорее не заветами Ленина, а идеями многочисленных мистико-религиозных сект, которые в изобилии встречаются в русской истории. Труд отменяется не как завоевание коммунизма, а поскольку есть солнце со своей мощью и теплом, которое дарит жителям бесконечной степи все необходимое для их существования. Трагической характеристикой чевенгурского коммунизма является истребление всех буржуев поселения во имя установления настоящего коммунистического строя. Более того, массовое убийство также определяется как второе пришествие или явление, в попытке таким образом провести параллель между коммунистическим обществом на земле и раем на небе: это, якобы, те два места, где живут праведники.

Ключевые слова: Чевенгур, Андрей Платонов, воскрешение мертвых, сексуальные отношения, справедливость, социал-коммунистическая работа, райское коммунистическое общество.

The author analyses the main themes underpinning the structure of Andrey Platonov's novel Chevengur. He starts by reflecting on the overloaded, fragmented and bewildering writing style adopted by Platonov. Then he investigates the influence of Nikolay Fyodorov's theory on the resuscitation of the dead on the novel. The author highlights that the absence of women in Chevengur inevitably leads male inhabitants to homosexuality. Rather than Leninist dictates, the communism practiced in the village seems to resemble the social project of one of the many mystical-religious sects that we encounter in Russian history. Work is abolished not as a conquest of communism, but because there is already 
the sun, which, with its might and its warmth, provides the inhabitants of the boundless steppe with the products necessary for their subsistence. The tragic element of Chevengurian communism consists in the extermination of all the bourgeois of the village in the name of the establishment of a true and authentic communist system. Furthermore, the massacre will be termed second coming or parousia, thus seeking to establish a precise correspondence between communist society on earth and celestial Heaven as the two places where the righteous live.

Key words: Chevengur, Andrey Platonov, resuscitation of the dead, sexual relations, justice, social-communist work, heavenly communist society.
Жизнь происходит от «неустойчивых равновесий».
Если бы равновесия везде были устойчивы, не было бы и жизни.
Но неустойчивое равновесие - тревога, «неудобно мне», опасность. Мир вечно тревожен, и тем живет.
Какая же чепуха эти Солнечный город и Утопия: суть коих вечное счастье. Т. е. окончательное «устойчивое равновесие». Это не «будущее», а смерть.

Василий Розанов (Розанов 1970a: 102).

1. Читая роман Чевенгур (1927-1929) Андрея Платонова (1899-1951), мы сталкиваемся с переполненным, перенасыщенным текстом, кажется, как будто автор находится во власти неудержимого потока сознания, так много идей, размышлений, суждений теснятся в романе, но они не всегда находят должное развитие и приводят читателя в состояние замешательства. Как заметил во свое время Иосиф Бродский, даже самая обычная фраза в его прозе может смутить читателя, достаточно необычного положения слова или особенной интонации, или всего лишь неожиданного эпитета, и читатель уже сомневается, правильно ли он понял (Brodskij 1987: 101).

Общепризнанным является мнение, что Платонов писал, используя новый язык советской эпохи, его фразеологию, стилистику, систему понятий, созданную основателями советского строя. Этот язык быстро «становится инструментом коммуникации и орудием формирования жителя идеального общества» (Геллер 1999: 272). И на самом деле, внешне якобы независимые мысли граждан оказываются часто лишь механическим повторением лозунгов, созданных властью.

Эта особенность мышления позволяет нам проникнуть в процесс формирования суждений героев Чевенгура, для большинства которых мыслительная деятельность является сложной задачей. Например, Федор Достоевский ${ }^{1}$ :

[...] медленно вбирал в себя слова Дванова и превращал их в видимые обстоятельства. Он не имел дара выдумывать истину, и мог ее понять, толь-

1 Речь идет об уполномоченном вольревкома деревни Ханские Дворики который, будучи Игнатием Мошонковым, стал называть себя именем писателя, чтобы увековечить его славное имя. На самом деле подобное изменение имени напоминает нам второе крещение, которому подвергали себя члены некоторых сект в России, второе крещение символизировало рождение в новой вере. В новой действительности романа это было рождение в коммунистической вере. 
ко обратив мысли в события своего района, но это шло в нем долго: он должен умственно представить порожнюю степь в знакомом месте, поименно представить на нее дворы своего села и посмотреть, как оно получается (Платонов 2018а: 107).

А Копенкин, напротив:

— Говори безгранично, до вечера времени много, — сказал Копенкину председатель. Но Копенкин не мог плавно поговорить больше двух минут, потому что ему лезли в голову посторонние мысли и уродовали одна другую до невыразительности, так что он сам останавливал свое слово и с интересом прислушивался к шуму в голове (Платонов 2018а: 117).

Когда коммунисты из Чевенгура пытались думать, их голова превращалась в странную машину, которая пыхтела, громыхала и часто глохла, не произведя никакой мысли, а только один шум. Большевик Кирей, например, «стал слушать шум в своей голове и ожидать оттуда думы, пока у него от усердия и прилива крови не закипела сера в ушах» (Платонов 2018a: 230). Исследователь Евгений Яблоков отмечает:

Процесс 'думания' часто выглядит как нарочитый, писатель неоднократно фиксирует разрыв между отвлеченным 'думанием' и интуитивным, спонтанным делом. [...] В романе Чевенгур эта антиномия реализована почти пародийно: Чепурный 'ощущает', а Прокофий улавливает интуиции Чепурного и формулирует их словесно, заведомо искажая (Яблоков 1992: 232).

Подобным образом в Котловане (1929) рабочий Чиклин «думать мог с трудом и сильно тужил об этом - поневоле ему приходилось лишь чувствовать и безмолвно волноваться» (Платонов 2018б: 387).

В Чевенгуре многие персонажи описываются подобным образом в отношении процесса мышления, так как эта деятельность не требовалась и не была предусмотрена политическим строем, или же это была индивидуальная неспособность мыслить так называемых «чудаков», в любом случае, герои ограничиваются произнесением отдельных кратких фраз и не в силах ни аргументировать свою мысль, ни облечь свои мысли в более или менее связные речи.

Выражаясь на языке своего времени, времени построения нового мира, Платонов полностью отдает себе в этом отчет. На первый взгляд он лишь сообразуется с языком утопического общества, но в то же время разоблачает его «бездны» (Бродский 1973: 6), осмысляя и используя опыты русского авангарда по преодолению языковой инертности и утверждению самовитого слова как такового. И на самом деле этот трудный, в муках рождающийся язык, нагруженный словосочетаниями, который предлагает нам автор, не является языком утопии, но лишь пользуется различными приемами как, например, сдвиг. В живописи кубистов этот термин означал смещение объекта или его части в необычный план, создавая таким образом видение этого объекта (или его части) одновременно с нескольких точек зрения, с целью показать непривычные связи между объектами или связать 
между собой несочетаемые элементы. Этот прием стал характерным для всего русского авангарда, не только в живописи, но и в литературе, где с его помощью слова обретали новые смыслы, перемещаясь из привычных контекстов в необычные (претерпевая семантические сдвиги), появилась даже новая дисциплина, основанная на приеме сдвига: сдвигология. Таким образом можно заметить, что в некоторых описаниях Платонов часто использует прием сдвига, в этой связи необходимо переосмыслить восприятие текста, обнаруживая, возможно, метафоры там, где ранее текст воспринимался как реалистическое повествование. Помимо приема сдвига в манере письма Платонова мы встречаем «стяжки», сокращения до нескольких слов сложных понятий, и избыточные слова (Дооге 2005: 410417), которые дают читателю избыток информации, возможно вследствие литературного замысла. Встречаются в тексте также ассоциации, явления синестезии и различные тропы, при помощи которых автор рассеивает недоумение читателя из-за отсутствия аргументации или рассуждений, не высказанных тем или иным персонажем, и таким образом внося ясность. Все эти приемы ${ }^{2}$ служат для создания языка, тяготеющего к вневременным категориям и конструкциям (Бродский 1973: 5), мы могли бы определить его как метафизический (Эпштейн 2006: 150). Поэтому выше мы говорили о перенасыщенной различными приемами и перегруженной возможными смыслами манере письма (Дооге 2007: 1-663).

2. Начало и финал романа отдают достойную дань философским размышлениям Николая Федорова (1829-1903), религиозного философа и оригинального русского мыслителя, о котором с глубоким уважением отзывались такие известные писатели и философы как Федор Достоевский, Лев Толстой и Владимир Соловьев. Ключевой темой его доктрины, представленной в Философии общего дела, является всеобеее воскрешение из мертвых, которое произойдет с помощью науки и техники. Николай Бердяев уточняет: «Проблема Федорова не воскресение мертвых, в которое всегда верили христиане, а воскрешение мертвых» (Бердяев 1989: 287). По Федорову, «[...] это не только христианское чаяние или императив, выдвинутый в его учении, а объективный закон истории, нравственной природы человека» (Семенова 1995: 20). Он считает, что каждый человек живет за счет предков и должен отдать им должное:

У нас нет ничего своего, нами произведенного, а все даровое, точнее, долговое; [...] мы получили жизнь от своих отцов, кои в таком же долгу у своих родителей, и т. д.; рождение есть передача долга, а не уплата его. [...] Сознание, что этот долг не оплачен, есть сознание своей зависимости, рабства,

2 Хотя в литературной критике разных лет много раз отмечалось присутствие в произведении Платонова приема остранения (описанного Виктором Шкловским), исследователь Ольга Меерсон, напротив, указывает, что в языке Платонова присутствует скорее неостранение, благодаря которому обнаруживается эсхатологическая аксиология писателя (Меерсон 2016: 37). 
невольности, смертности - словом, небратства. В неоплаченном долге заключается наказание рабством, смертью. Оплаченный долг есть возвращение жизни своим родителям, т. е. долга своим кредиторам и через то - свободы себе (Федоров 1982: 162-163).

Реальному воскрешению мертвых отведено также центральное место в его проекте «регуляции» природы. В природу должны быть введены воля и разум, что ознаменует новый этап ее эволюции. Но тем не менее, для успешного воскрешения мертвых люди должны понять прежде всего причины, из-за которых в мире нет согласия, нет братского отношения между народами, группами людей, отдельными личностями и даже между родственниками и близкими. Как только человек достигнет понимания самого себя и других в духовном смысле, он перейдет в состояние «братства» и только тогда сможет успешно принять участие в общем деле воскрешения мертвых.

Необходимость перехода в общее состояние братства неизбежно отсылает нас к евангельскому учению: от милостивых, которые будут помилованы до необходимости примириться с братом (Мф. 3, 24).

Победа над смертью привела бы к неизбежному перенаселению земли и, вследствие этого, исчерпанию жизненных ресурсов, поэтому Федоров считает завоевание космоса человеком единственным путем спасения человеческого рода: «[...] порожденный крошечною землею, зритель безмерного пространства, зритель миров этого пространства, должен сделаться их обитателем и правителем» (Федоров 1995: 243). Жажда межзвездных путешествий усилится и еще более распространится в России в 20-х годах двадцатого столетия благодаря философии космоса Константина Циолковского (1857-1935), глубокого ценителя идей Федорова.

Чевенгур открывается фигурой Дмитрия Иваныча, рыбака с озера Мутево и отца главного героя романа Александра (Саши) Дванова. Дмитрий в отличие от других людей не боится перейти границу между жизнью и смертью. Из любопытства он решает утопиться в озере: «он хотел посмотреть - что там есть» (Платонов 2018а: 11), задержаться там ненадолго, затем вернуться к жизни и рассказать односельчанам, что он видел. Тайна смерти и угасание тела всегда возбуждали интерес, если не одержимость, человеческого разума, фантазии, духа, были причиной тревоги, любопытства, страха, образование религий было ответом на эту одержимость. Но в отличие от того, на что рассчитывал Дмитрий Иваныч, совершенное действие стало не «экскурсией в смерть», а окончательным выбором. Возвращения в мир, т. е. воскрешения не произошло, и через три дня односельчане вытаскивают тело утопленника из воды и погребают рядом с кладбищенской оградой. Во время похорон сын Дмитрия Иваныча Александр, тогда еще маленький мальчик, задает вопросы Захару Павловичу, местному чудаку-изобретателю, который, естественно, не верил в воскрешение мертвых и пытался отговорить отца Саши от самоубийства: «Нет там ничего особого: так что-нибудь тесное» (Платонов 2018а: 11), — предупре- 
ждал он. В ответах на вопросы Александра Захар не одобряет действий его отца, считая их проявлением безумия («сдуру»). Следующее его замечание — «Не скоро ему рыбу ловить придется» (Платонов 2018а: 11) — может показаться обращением к идеям Федорова: вот он умер, но через некоторое время будет воскрешен и сможет снова ловить рыбу, но на самом деле в словах Захара лишь ироничная оценка глупости Дмитрия Иваныча, который искал и желал собственной смерти. Мы сразу же понимаем, что речь идет об иронии, из обращения Захара Павловича к Александру: «Попрощайся с отцом - он мертвый на веки веков» (Платонов 2018а: 12). Выражение «на/во веки веков» соответствует латинскому «in saecula saeculorum», и не оставляет сомнений: Дмитрий не будет воскрешен в скором времени, а воскреснет, как верят все христиане, в день Страшного Суда ${ }^{3}$.

Имея такое начало, роман завершается фигурой Александра Дванова, который, как уже было сказано, является главным действующим лицом романа. Александру удается избежать ярости неизвестного казачьего войска, миссией которого было разрушение утопии Чевенгура и уничтожение его жителей. Покинув место столкновения с казаками, Александр через несколько дней пути, находит старую дорогу, по которой шел в детстве, проезжает через свою родную деревню и оказывается на берегу озера Мутево:

Он оглядел все неименное, смолкшее озеро и насторожился, ведь отец еще остался - его кости, его жившее вещество тела ${ }^{4}$, тлен его взмокавшей по̀том рубашки, — вся родина жизни и дружелюбия. И там есть тесное, неразлучное место Александру, где ожидают возвращения вечной дружбой той крови, которая однажды была разделена в теле отца для сына. Дванов понудил Пролетарскую Силу войти в воду по грудь и, не прощаясь с ней, продолжая свою жизнь, сам сошел с седла в воду — в поисках той дороги, по которой когда-то прошел отец в любопытстве смерти, а Дванов шел в чувстве стыда жизни перед слабым, забытым телом, остатки которого истомились в могиле, потому что Александр был одно и то же с тем еще не уничтоженным, теплящимся следом существования отца (Платонов 2018a: 355).

Александр идет по следам отца и, как отец, утопает в озере, хотя автор и не говорит этого открыто. Следует ли он таким образом учению Федорова в поиске жизни в смерти? В процитированном отрывке мы видим, что Александр спускается в воду озера, чтобы пройти путь, проделанный когда-то отцом, но при этом «продолжая свою жизнь». Что означают эти слова? Уверенность в том, что можно уходить из жизни в смерть и наоборот? Не достаточно ли ему было опыта отца, своим примером доказавшего несостоятельность этой мысли? Или же он непоколебимо верил в воскреше-

3 Не очень понятна интерпретация Валерия Вьюгина (2004: 127), по мнению которого «на веки веков» могло бы означать «мертвый на очень долгое время, но все же не навсегда». Конечно, как любой другой человек, Дмитрий тоже воскреснет в день Страшного Суда, но не ранее, как предполагала теория Федорова.

4 Тело отца маленького Александра, как было сказано, вытащили из озера и через три дня погребли рядом с кладбищем, поэтому в озере не могли оставаться ни его кости, ни какие-либо другие останки. 
ние мертвых? Как-то ночью Александру приснился один день из детства, и он снова с нежностью ощутил объятия отца на берегу озера Мутево, он тогда спросил себя, почему «та жизнь, обещанная навеки, теперь не возвращается», другими словами, почему его отец не был воскрешен (Платонов 2018а: 209). За несколько строк до этого уже его отец жалуется во сне, что воскрешения не происходит: «Не скучай, — сказал отец. — И мне тут, мальчик, скучно лежать. Делай что-нибудь в Чевенгуре: зачем же мы будем мертвыми лежать...» (Платонов 2018а: 210). Несмотря на то, что отец не был воскрешен, сын решает тем не менее закончить свою жизнь таким же образом. Возникает вопрос, действительно ли Александр верил в непременное воскрешение мертвых или же это был акт самоубийства? Можно также расценить погружение навсегда в воды озера как возвращение в лоно матери, покинувшей его так рано.

Повествователь в романе указывает на существование в человеке некоего особенного присутствия:

Но в человеке еще живет маленький зритель - он не участвует ни в поступках, ни в страдании - он всегда хладнокровен и одинаков. [...] Он существовал как бы мертвым братом человека: в нем все человеческое имелось налицо, но чего-то малого и главного недоставало. Человек никогда не помнит его, но всегда ему доверяется - так житель, уходя из дома и оставляя жену, никогда не ревнует к ней швейцара.

Это евнух души человека (Платонов 2018а: 90).

Мы присутствуем при очевидном раздвоении личности, из чего можно заключить, что каждый из нас хотел бы одновременно участвовать в событии и наблюдать его. Подобным образом хотели бы вести себя Александр и его отец, однако, как мы видели, они были лишь участниками, но не наблюдателями.

В Котловане, напротив, Вощев никем не контролируется, не претерпевает раздвоения личности, чтобы стать наблюдателем, но тем не менее:

И он ощущал в темноте своего тела тихое место, где ничего не было, но ничто ничему не препятствовало начаться. Как заочно живущий, Вощев гулял мимо людей, чувствуя нарастающую силу горюющего ума и все более уединяясь в тесноте своей печали (Платонов 2018б: 365).

Без сомнения, каждый разумный персонаж считает очень ценным это место, скрытое в собственном теле, где ничего нет и где все может начаться, потому что, потеряв это особенное место человек потеряет свое лицо, станет одним из многих, безымянным гражданином в массе других.

В литературной критике, однако, образ «евнуха души» или «хранителя собственного я» (по определению Lane 2018: 49) был связан, в частности, с темой кастрации, отсутствия желания и сложного пуританского отношения к сексуальности не только Дванова, но и всех жителей Чевенгура, о которых мы сейчас будем говорить. 
Помимо уже упомянутых случаев, проблески идей Федорова то тут, то там мелькают в тексте романа, а в одном отрывке проявляются наиболее ярко:

Направо от дороги Дванова, на размытом оползшем кургане, лежал деревенский погост. Верно стояли бедные кресты, обветшалые от действия ветра и вод. Они напоминали живым, бредущим мимо крестов, что мертвые прожили зря и хотят воскреснуть. Дванов поднял крестам свою руку, чтобы они передали его сочувствие мертвым в могилы (Платонов 2018а: 94).

3. И тем не менее, коммунизм, который строят в Чевенгуре, вступает в конфликт с некоторыми теориями Федорова, прежде всего с идеей о кровных связях (т. е. не признается наличие какого бы то ни было долга перед родителями) и, следовательно, с концепцией семьи вообще, а также с сексуальностью каждого из жителей. И на самом деле, коммунистам в Чевенгуре следовало стремиться к целомудрию: «У нас супруг нету: одни сподвижницы остались» (Платонов 2018а: 171), заявляет председатель Революционного комитета Чепурный с убежденностью, похожей на заявления скопцов из известной русской секты (Толстая-Сегал 1994: 70) романа, однако, даже убежденные приверженцы исключительно мужского коммунизма вынуждены уступить перед необходимостью найти женщин для народа (Borenstein 2000: 237-242):

Яков Титыч увидел, как многие люди молча скрылись из Чевенгура, и тогда он явился к Прокофию. - Езжай за женами народу, — сказал Яков Титыч, - народ их захотел. Ты нас привел, веди теперь женщин, народ отдохнул - без них, говорит, дальше нетерпимо (Платонов 2018а: 284).

На самом деле, одна женщина в Чевенгуре все же оставалась: Клавдюша, «словно она была коммунисткой будущего», говорит про нее автор (Платонов 2018а: 182), естественно, она не соблюдала целомудрие, но была благосклонна только к любимому Прокофию. Несмотря на то, что женщины тоже боролись за установление нового порядка, как только что упомянутые сподвижницы, не говоря уже о Розе Люксембург, которую почитал Копенкин и в которую он был влюблен на расстоянии, большевики из Чевенгура воспринимают их как существ опасных для первоначального социализма:

Но Чепурный и сам не мог понять дальше, в чем состоит вредность женщины для первоначального социализма, раз женщина будет бедной и товарищем. Он только знал вообще, что всегда бывала в прошлой жизни любовь к женщине и размножение от нее, но это было чужое и природное дело, а не людское и коммунистическое; для людской чевенгурской жизни женщи-

5 Об отказе от брака и идее сохранения целомудрия см. в Евангелии от Матфея: «Ибо есть скопцы, которые из чрева матернего родились так; и есть скопцы, которые оскоплены от людей; и есть скопцы, которые сделали сами себя скопцами для Царства Небесного» $(19,12)$. Напомним, что одна из наиболее значимых мистических русских сект, основанная в 18 веке, состояла из скопцов, т. е. из мужчин «сделавшихся евнухами». 
на приемлема в более сухом и человеческом виде, а не в полной красоте, которая не составляет части коммунизма, потому что красота женской природы была и при капитализме, как были при нем и горы, и звезды, и прочие нечеловеческие события. Из таких предчувствий Чепурный готов был приветствовать в Чевенгуре всякую женщину, лицо которой омрачено грустью бедности и старостью труда, - тогда эта женщина пригодна лишь для товарищества и не составляет разницы внутри угнетенной массы, а стало быть, не привлекает разлагающей любознательности одиноких большевиков. Чепурный признавал пока что только классовую ласку, отнюдь не женскую (Платонов 2018a: 228-229).

Чепурный, таким образом, с убежденностью отвергает женские ласки, принимая мужские. Можно встретить по этому поводу отрывки в романе, которые допускают различные толкования:

Теперь Копенкин тоже равнодушен к Чевенгуру и хочет уехать к своей барышне - Розе Люксембург, а чевенгурцы не имеют барышни, и им придется остаться одним и утешаться между собой (Платонов 2018а: 262).

Сложно представить себе, что мужчины в Чевенгуре довольствовались случайными ласками, чтобы утешаться, т. е. удовлетворять свои сексуальные порывы, более правдоподобным кажется, что они прибегали к онанизму или к гомосексуальным действиям. Тот же Копенкин, в частности, не мог найти достаточного ответа своей сексуальности в поклонении «барышне Розе Люксембург», т. к. она была идеальная, далекая и уже покойная. Несмотря на преданность или скорее страсть к образу Люксембург, он поддерживал достаточно тесную дружбу с Александром Двановым: «Вечером Дванов и Копенкин поцеловались среди дороги, и обоим стало бессмысленно стыдно» (Платонов 2018а: 143). Испытывать стыд за невинный поцелуй другу, в стране, где все друг друга обнимают и целуют? Возможно, они стыдились сексуального желания, которое испытывали по отношению друг к другу.

Когда старый большевик Жеев подошел к фаэтону и поцеловал Прокофия в засохшие губы, он тут же добавил в объяснение своего поступка: «Проша, не забудь и женщин отыскать, хоть бы нищенок. Они, брат, для нежности нам надобны, а то видишь - я тебя поцеловал» (Платонов 2018а: 228). Другими словами, товарищ Жеев напоминает Прокофию, что в отсутствие женщин жители Чевенгура будут вынуждены прибегать к гомосексуальным действиям.

Тем временем, дружба между Двановым и Копенкиным становится все более страстной:

Копенкин настиг Дванова сзади; он загляделся на Сашу с жадностью своей дружбы к нему и забыл слезть с коня. Пролетарская Сила первая заржала на Дванова, тогда и Копенкин сошел на землю. Дванов стоял с угрюмым лицом - он стыдился своего излишнего чувства к Копенкину и боялся его выразить и ошибиться. Копенкин тоже имел совесть для тайных отношений между товарищами, но его ободрил ржущий повеселевший конь. 
— Саша, - сказал Копенкин. - Ты пришел теперь?.. Давай я тебя немного поцелую, чтоб поскорей не мучиться (Платонов 2018а: 279).

Поскольку при встрече присутствовал также третий человек, Чепурный, сложно представить, чтобы отношения могли перейти границы дружбы, однако, зададимся вопросом, что стоит за фразой: «Копенкин тоже имел совесть для тайных отношений между товарищами»? Кажется очевидным, что друзья испытывали сильное сексуальное влечение друг к другу и, вследствие этого, имели «тайные отношения», идет ли речь о не практикуемой гомосексуальности, метафизической или о чем-то другом, это нам знать не дано (Парамонов 1987: 333-372)6. В защиту нашей гипотезы можно процитировать и некоторые другие фрагменты романа, например, нижеследующий, показательный своей ясностью:

Он [Копенкин] тратил свою скорбь на усердие труда, он незаметно хотел привлечь Дванова к красоте Розы Люксембург и сделать для него счастье, раз совестно сразу обнять и полюбить Дванова (Платонов 2018а: 301).

Со своей стороны, мы не утверждаем, что объятия между мужчинами, упоминание о которых часто встречается в тексте, всегда скрывают в себе определенные сексуальные порывы. Напротив, это случается только в нескольких эпизодах. Обычно объятия представляют собой рефлекторные действия, направленные на поиск тепла в соответствии с известным энтропическим принципом, гласящим, что между двумя телами всегда достигается термодинамическое равновесие. Вот тому яркий пример:

— Не пугайся, - сказал ему привалившийся человек. - Я озяб во сне, вижу, ты лежишь, — давай теперь обхватимся для тепла и будем спать (Платонов 2018а: 74).

4. Справедливость, которая вершится в населенном пункте, где строится коммунизм, обращена к так называемым «прочим», к тем, кто лишен всего, кроме собственного тела. Они строго отделяются от пролетариата, образуя экономически и культурно деградировавший класс, лишенный, по Марксу, классового сознания. Когда Прокофий сообщает, что привез в Чевенгур пролетариат и прочих, Чепурный спрашивает: «Какие прочие?». «Прочие и есть прочие - никто. Это еще хуже пролетариата», - отвечает Прокопий (Платонов 2018а: 245).

Таким образом, в Чевенгуре больше не преобладают отношения типа отец-сын, там воцаряется товарищество, в соответствии с заветными установлениями коммунизма и древнерусскими общинными традициями.

${ }^{6}$ Исследователь Элиот Боренштейн, учитывая факт отсутствия женщин в Чевенгуре, полагает, что тесные отношения между мужчинами, в которых, однако, гомосексуальность отходит на второй план, обусловлены тем, что почти все жители в Чевенгуре выросли без отца и находились в поиске модели отцовства. Если принять версию, что гомосексуальность остается на втором плане, невозможно было бы объяснить только что процитированные нами отрывки романа (Borenstein 2000: 242-250). 
На самом деле, здесь мы имеем дело скорее не с коммунизмом марксистского типа, принятым и насаждаемым Лениным и, впрочем, достаточно чуждым простецам из Чевенгура, а с воплощением одного из многих замыслов, которые веками лелеяли многочисленные мистико-пророческие русские секты, вдохновляемые идеей преображения существующего мира (Эткинд 2019: 5-642). Николай Бердяев пишет:

То, что называли у нас двоеверием, т. е. соединение православной веры с языческой мифологией и народной поэзией, объясняет многие противоречия в русском народе. [...] Известна склонность русского народа к разгулу и анархии при потере дисциплины. [...] Русские - бегуны и разбойники. И русские - странники, ищущие Божьей правды. Странники отказываются повиноваться властям. Путь земной представлялся русскому народу путем бегства и странничества. Россия всегда была полна мистико-пророческих сект. [...] В духовных стихах была высокая оценка нищенства и бедности. Излюбленная тема их - безвинное страдание. В духовных стихах есть очень большое чувство социальной неправды (Бердяев 2015: 10-11).

Эти странные персонажи с простой речью, мечтатели и странствующие мудрецы, которые наполняют роман, пользуются полным одобрением автора и могут рассматриваться как постреволюционная версия традиционных русских странников, ищущих Божью правду, или же как юродивые (Bethea 1989: 158).

В конце XIX века и в первые годы XX-го в России возникла консервативная группа «Богоискательство», членами которой среди прочих были также Николай Бердяев, Сергей Булгаков, Дмитрий Мережковский, Зинаида Гиппиус, Василий Розанов. В поисках путей сближения между Церковью и интеллигенцией они пытались, при помощи организации религиозно-философских собраний и публикации книг и журналов, научить тому, как строить новые отношения между людьми, основанные на принципах христианства, единственного пути достижения истинного освобождения личности человека.

Практически в ответ богоискателям Анатолий Луначарский, Владимир Базаров, Максим Горький и другие представители интеллигенции основали в первом десятилетии XX века группу «Богостроительство», которая понимала религию в ее наиболее аутентичном смысле, ставя в центр не Бога, а человека в его социальности. Речь шла об обожании коллектива, работы, прогресса, любви к жизни, способном, по их мнению, объединить социалистические идеалы и повседневную реальность.

В годы революции на защиту социально-ориентированной религии становились такие известные деятели культуры, как Андрей Белый, Александр Блок, Сергей Есенин, Николай Клюев, которые, объединившись вокруг фигуры Иванова-Разумника, в 1917-1918 опубликовали два номера альманаха Скифы. В октябрьском восстании они усматривали великую силу, идущую с Востока, которая очистит общество от буржуазного шлака и духовно преобразит общество. В общем, мессианско-пророческие эле- 
менты и склонность к анархии всегда характеризовали русскую историю, начиная с той массовости, с которой народ следовал за разного рода обманщиками, стремившимися захватить царский престол.

5. В социал-коммунистической доктрине работа всегда рассматривалась как основа нового общества, символ человеческого достоинства и источник благосостояния. Известна фраза Ленина, которую он повторял во многих трудах: «Кто не работает, тот да не ест» (Ленин 1974: 357), хотя это ни что иное, как вариант цитаты из Второго Послания апостола Павла Фессалоникийцам: «Если кто не хочет трудиться, тот и не ешь» $(3,10)$. Это утверждение Ленина считалось таким важным, фундаментальным для социалистического общества, что было закреплено в статье 12 Конституции Советского Союза 1936 года: «Кто не работает, тот не ест». Маркс предвидел, что на более развитом этапе коммунистического общества, «когда труд перестанет быть только средством для жизни, а станет сам первой потребностью жизни» (Маркс 1961: 20), это общество сможет начертать на своих знаменах еще одну не менее знаменитую фразу: «Каждый по способностям, каждому по потребностям!» (Маркс 1961: 20), ставшую затем общеизвестной в несколько измененном варианте: «От каждого по способностям, каждому по потребностям!» В Чевенгуре, однако, отложив марксистское учение, странные жители, его населяющие, сразу же установили коммунизм. Можно усмотреть в этом пародию на революционный романтизм, провозглашенный Лениным (Seifrid 1992: 103). Естественно, они не проводили время за изучением трудов Маркса, им было достаточно услышать о них на митингах:

Копенкин не успел прочитать Карла Маркса и смутился перед образованностью Чепурного. ла Маркса?

— А что? — спросил Копенкин. — У вас здесь обязательно читают Кар-

Чепурный прекратил беспокойство Копенкина:

- Да это я человека попугал. Я и сам его сроду не читал. Так, слышал кое-что на митингах — вот и агитирую (Платонов 2018а: 178).

Таким образом, первым делом они решили отменить труд:

Копенкин уже спрашивал Чепурного - что же делать в Чевенгуре? И тот ответил: ничего, у нас нет нужды и занятий - будешь себе внутренне жить! У нас в Чевенгуре хорошо - мы мобилизовали солнце на вечную работу, а общество распустили навсегда! (Платонов 2018а: 179).

Через несколько страниц будет дано более мотивированное объяснение отмены трудовой деятельности в Чевенгуре:

[...] Прокофий дал труду специальное толкование, где труд раз навсегда объявлялся пережитком жадности и эксплуатационно-животным сладострастием, потому что труд способствует происхождению имущества, а имущество - угнетению; но само солнце отпускает людям на жизнь вполне доста- 
точные нормальные пайки, и всякое их увеличение - за счет нарочной людской работы - идет в костер классовой войны, ибо создаются лишние вредные предметы (Платонов 2018а: 187).

Хотя в Чевенгуре никогда не читали произведения Маркса, но сразу же перешли к реализации утопии раннего периода творчества немецкого философа, в соответствии с которой труд будет упразднен, когда общество достигнет высшей точки развития коммунизма. В работах более позднего периода, однако, Маркс скорректировал свои юношеские взгляды, повторяя неоднократно, что он не имел в виду резкой и окончательной отмены трудовой деятельности, но труда в том виде, в каком знало его человечество на протяжении веков, изменив основной способ производства на новый, не предусматривающий эксплуатацию.

Пока «жители отдыхали от веков угнетения» (Платонов 2018a: 188) или двигались неспеша, потому что «спешили одни буржуи, им жрать и угнетать надо было» (Платонов 2018а: 181), солнце работало «за всех и для каждого» (Платонов 2018а: 187) так усердно, что ему было присвоено в Чевенгуре звание «всемирного пролетария» (Платонов 2018а: 187). Солнце, которое «в двенадцать раз больше земли» (Платонов 2018а: 182), своей энергией и теплом дает жителям Чевенгура и необъятной степи необходимые продукты для существования, поэтому работать больше нет необходимости. Речь идет только о необходимом для поддержания существования, а не о жизни в изобилии. И даже в этом аскетическом отношении к повседневной жизни коммунисты Чевенгура, кажется, не столько следуют принципам коммунизма, сколько учениям, проповедуемым русскими сектами.

Лет за десять до написания Чевенгура, Василий Розанов опубликовал в виде небольших книжек-выпусков, посылаемых подписчикам, цикл блестящих размышлений под названием Апокалипсис нашего времени, в них он выразил некоторые соображения о солнце, эхо которых звучит в словах жителей Чевенгура, естественно, облеченных в революционные формы:

Но скажем: какого же солнце, которое неизреченным тьмам народа дает хлеба, — дает как «по службе», по «должности», почти «по пенсии». Дает и может дать. Дает и значит хочет дать?

У солнца - воля и ...хотение?

Но... тогда «ваал-солнце»? ваал-солнце - финикиян?

И тогда «поклонимся Ему»? Ему и его великой мощчи? (Розанов 1970б: 458).

Во многих культурах, мифологиях, религиозных верованиях присутствует образ солнца: Ра-бог-солнце древних египтян, Гелиос-божество древних греков, Хорс-древнерусский бог солнца, знаменитая книга Город солнца Томмазо Кампанеллы и фантастический рассказ Сон смешного человека Достоевского, в котором повествователь посещает планету детей солнца. В начале XX века солнце завораживало русских символистов. В сборнике стихотворений 1903 года Будем как Солнще, Константин Баль- 
монт признается: «Я в этот мир пришел, чтоб видеть Солнце» (Бальмонт 1980: 120) и Вячеслав Ив. Иванов в своем произведении Cor ardens 1911 года слагает «Хвалу солнцу», поскольку оно «вожатый ангел Божий» (Иванов 1974: 230). И вот, в драме Леонида Андреева К звездам 1906 года мы слышим из уст тридцатилетнего пролетария Трейча характеристику солнца, близкую к той, что дают большевики из Чевенгура: «Товарищи, солнце ведь тоже рабочий!» (Андреев 1913: 216).

В отличие от символистов с их агрессивным, скандальным бунтарством, выступающим против любых институтов и отрицающих достижения прошлого, русские кубофутуристы в первое десятилетие ХХ века были увлечены солнцеборчеством. После того, как Филиппо Томмазо Маринетти в своем манифесте «Убьем лунный свет!», несмотря на название выразил скорее свое презрение к солнцу, в Петербурге в 1913 году была создана монументальная постановка Победа над солнцем Алексея Крученых на музыку Михаила Матюшина с вступлением-манифестом Велимира Хлебникова и костюмами Казимира Малевича, в которой солнце было побеждено и взято в плен. В 1920 году Владимир Маяковский, певец совершившейся социал-коммунистической революции, возвращается к мотиву солнцеборчества, обвиняя солнце в тунеядстве и пустом времяпровождении в облаках: «Дармоед! / занежен в облака ты» (Маяковский 2013: 144).

Возвращаясь к Платонову, мы можем узнать из его статьей, опубликованных в двадцатых годах, что он был достаточно технически осведомлен и интересовался использованием солнечной энергии в целях развития социалистической промышленности (Яблоков 2001: 227-232). Солнце присутствует в прозвище Чепурного, «Японец», т. к. на флаге Японии на самом деле изображено восходящее солнце (Catteau 1984: 39-50). Предположив существование некоего фольклорного подтекста, можно было бы связать псевдоним «Японец» с царством Опоньским, т. е. японским, в свою очередь имеющим отношение к распространенной легенде о Беловодье (Günther 1992: 214)7. В учении секты хлыстов солнце якобы напрямую общалось с силами Святого Духа (Кубо 1997: 71-78), в Чевенгуре, напротив, вдохновившись революционным словом, оно становится неутомимым рабочим, настоящим пролетарием, который трудится, помогая всем прежде угнетенным.

В своем Weltanschauung Платонов задумывается над построением мира и образом человека в соответствии с четырьмя стихиями греческой философии: земля, огонь, воздух и вода (Дмитровская 1998: 3-6). Мы встречаем в романе весьма показательный отрывок:

— Раз дождь идет, а потом солнце светит, то тезисы ты не жалей, успокоительно сказал Копенкин [...]

— Как же так? Солнце тебе — раз тезис! Вода — два, а почва — три.

7 Согласно легенде, царство Беловодье - вожделенная земля бегунов - о которых мы скажем чуть позже, располагалась на территории 70 островов, в море-океане, за китайской Страной. Острова были покрыты непроходимыми вековыми лесами, и зимы там были очень суровыми (Чистов 1967: 258). 
- А ветер ты забыл?

— С ветром — четыре. Вот и все (Платонов 2018а: 192).

Чепурный и Копенкин не выделяют среди стихий огонь, но упоминают солнце, добрый огонь, который не разрушает и является, как мы знаем, исключительным источником благоденствия. Саша Дванов даже слышит приятный шум горения: «воздух он ощутил тяжелым, как воду, солнце шумящим от горения огня» (Платонов 2018а: 68). Это солнце почти наверняка продолжит освещать коммунистическое общество в течение всего года, изменяя естественную смену сезонов и снабжая жителей Чевенгура и окружающей степи пропитанием в изобилии:

Кроме того - неизвестно, настанет ли зима при коммунизме или всегда будет летнее тепло, поскольку солнце взошло в первый же день коммунизма и вся природа поэтому на стороне Чевенгура (Платонов 2018а: 261).

Неотвратимо приближающийся приход осени с дождями и первыми холодами совпадет с разрушением Чевенгура и истреблением его жителей.

6. Оседлость и однообразие жизни в Чевенгуре нравились не всем. Мишка Луй считал, что коммунизм должен быть в движении, в перемещении, потому что, как скажет Нур-Мухаммед в повести Джан (1934-1935): «Кто ходит — тому всегда легче» (Платонов 1988: 495).

Не зная букв и книг, Луй убедился, что коммунизм должен быть непрерывным движением людей в даль земли. Он сколько раз говорил Чепурному, чтобы тот объявил коммунизм странствием и снял Чевенгур с вечной оседлости.

- На кого похож человек - на коня или на дерево: объявите мне по совести? - спрашивал он в ревкоме, тоскуя от коротких уличных дорог. [...] «Надо, чтобы человека ветром поливало, - убеждал Луй — иначе он тебе опять угнетением слабосильного займется, либо само собою все усохнет, затоскует — знаешь как? (Платонов 2018а: 188-189).

С победой коммунизма в Чевенгуре изменяется язык, но традиции остаются. На самом деле, самый значимый пример, которые мог иметь Луй, был пример русских странников. Небольшая группа монахов в Средние века положила начало явлению странничества, но со временем оно превратилось в социокультурное явление, которое вовлекало различные пласты общества. Несомненно, важный вклад в понятие движения, перемещения, скитания был внесен сектой бегунов, возникшей в конце 18 века в старообрядческой среде. Бегуны считали царя воплощением антихриста, и, соответственно, никонианская православная Церковь, все государственные законы, налоги и поборы, военная повинность, деньги, семья были в их глазах орудиями антихриста. Всегда гонимые за свои взгляды, они считали для себя единственным выходом порвать все социальные связи и бежать, т. е. проводить жизнь, скрываясь и постоянно меняя местонахождение, скитаясь, чтобы не попасть в руки прислужников власти (Чистов 1967: 241). 
В романе мотив светского скитания - это своего рода болезнь, которая поражает не только незначительных персонажей, таких как Мишка Луй, но особенно, среди главных героев, Захара Павловича, Дванова и Копенкина. Двое последних всегда в движении, более того:

[...] обоим всадникам стало легче, когда они почувствовали дорогу, влекущую их вдаль из тесноты населения. У каждого, даже от суточной оседлости, в сердце скоплялась сила тоски; поэтому Дванов и Копенкин боялись потолков хат и стремились на дороги, которые отсасывали у них лишнюю кровь из сердца (Платонов 2018а: 111-112).

При этом, нужно заметить, Чевенгур совсем не был царством оседлости. И на самом деле, в целях достичь по заветам коммунизма (которые в этом случае совпадали с христианскими), сближения и знакомства с другими людьми «все постройки стояли не на месте, а на ходу» (Платонов 2018a: 190). Считалось, что граждане смогут легче воспринимать телесность друг друга и познакомиться поближе, если будут жить в смежных помещениях, поэтому строения и дворы постоянно перемещались, таким образом, что близость была не только идеальная, но и пространственная. Коммунизм объединил бы телесно жителей Чевенгура, как Иисус Христос объединяет верующих и, преодолевая их индивидуализм, разрушая все барьеры, превратил бы все множество тел в одно единое тело (Рм. 12, 4-8; Гл. 3, 28; Еф. 2, 11-18; Ин. 17, 20-23) (Дмитровская 1995: 94). Постоянные перемещения сделали улицы такими узкими и извилистыми, что лошадь «Пролетарская Сила ${ }^{8}$, привыкшая к прямым плавным дорогам, волновалась и потела от частых поворотов» (Платонов 2018а: 190).

7. Установление коммунизма должно было принести мир и социальное спокойствие в Чевенгур, можно было бы прийти к строительству настоящего коммунизма, уничтожив буржуазию, считавшуюся смертельным врагом пролетариата и о коварстве и злобе которой жители были прекрасно осведомлены. По вине буржуев отношения между людьми стали невыносимыми. Например, товарищ Пиюся, встречаясь по дороге с буржуями, не раз бросался на них с кулаками, поскольку:

Со дня своего назначения председателем чрезвычайки он не имел душевного покоя и все время раздражался: ведь ежедневно мелкая буржуазия ела советских хлеб, жила в его домах (Пиюся до этого работал двадцать лет каменным кладчиком) и находилась поперек революции тихой стервой (Платонов 2018а: 197).

И наконец, Чепурный решил покончить раз и навсегда с классовыми противоречиями, приказав Пиюсе очистить город от всех угнетающих элементов. Деятельность последнего по выполнению этого приказа приведет

8 Так звали лошадь Копенкина, чьи характеристики напоминают чудесных коней из русских сказок (Михеев 2015: 38-39). 
к массовому убийству всех буржуев, что и было обозначено на предыдущих страницах романа как неизбежное второе пришествие. В литературной критике не раз отмечались многочисленные евангельские мотивы, которыми наполнено творчество Платонова, особенно роман Чевенгур, в котором появляется даже фигура Иисуса Христа (Livingstone 2003: 91-97):

По горизонту степи, как на горе, шел высокий дальний человек, все его туловище было окружено воздухом, только подошвы еле касались земной черты, и к нему неслись чевенгурские люди. Но человек шел, шел и начал скрываться по ту сторону видимости, а чевенгурцы промчались половину степи, потом начали возвращаться — опять одни (Платонов 2018а: 293).

В Евангелии Иисус не раз говорил о Своем втором пришествии или явлении в конце времен, чтобы передать царство Отцу (Мф. 24, 1-51; Мк. $13,1-37)$, тогда восстанут мертвые и Сын Человеческий проявит Себя во всей силе и славе (Мф. 24, 30). Однако, перед вторым пришествием Христа, как напоминает апостол Павел, будет отступничество и появление антихриста (2 Ф. 2, 3), который принесет великую скорбь:

Ибо тогда будет великая скорбь, какой не было от начала мира доныне, и не будет. И если бы не сократились те дни, то не спаслась бы никакая плоть; но ради избранных сократятся те дни (Мф. 24, 21-22).

Бог, по Своему милосердию, сократит дни конца, иначе в ужасной борьбе избранных и злых, даже избранные подвергаются опасности прельститься.

Второе пришествие, о котором говорится в Чевенгуре это изображение того, что произойдет в конце времен. Избранные Чевенгура (большевики) вступают в смертельную схватку со злыми (буржуазией), убивая их дважды, чтобы воспрепятствовать воскресению их душ: «Буржуев в Чевенгуре перебили прочно, честно, и даже загробная жизнь их не могла порадовать, потому что после тела у них была расстреляна душа» (Платонов 2018а: 196). Таким образом они думали распахнуть двери райского коммунистического общества там, где заканчивается история, как считал Чепурный:

- У нас всему конец.

— Чему ж конец-то? - недоверчиво спрашивал Гопнер.

— Да всей всемирной истории — на что она нужна? (Платонов 2018а: 159).

Через несколько страниц тот же Чепурный ответит:

- Какая кооперация? Какой тебе путь, когда мы дошли? Что ты, дорогой гражданин! Это вы тут жили ради бога на рабочей дороге. Теперь, братец ты мой, путей нету - люди доехали.

- Куда? - покорно спросил Алексей Алексеевич, утрачивая кооперативную надежду в сердце.

- Как куда? - в коммунизм жизни. Читал Карла Маркса?

- Нет, товарищ Чепурный.

- А вот надо читать, дорогой товарищ: история уже кончилась, а ты не заметил (Платонов 2018а: 178). 
Между коммунистическим обществом на земле и раем на небе устанавливается четкое соответствие: это те места, где живут праведники. Выражение «конец истории» будет подхвачено Двановым:

[...] и Дванов догадался, почему Чепурный и большевики-чевенгурцы так желают коммунизма: он есть конец истории, конец времени, время же идет только в природе, а в человеке стоит тоска (Платонов 2018а: 293).

Более того, кроме «конца истории» он поймет, что люди уже находятся при конце света, поскольку русская революция — это конец света:

Александр [...] верил, что революция - это конец света. В будущем же мире мгновенно уничтожится тревога Захара Павловича, а отец-рыбак найдет то, ради чего он своевольно утонул. В своем ясном чувстве Александр уже имел тот новый свет, но его можно лишь сделать, а не рассказать (Платонов 2018а: 56).

Подобно тому, как это происходит в раю, коммунистическое общество будет помогать и обогащать жизнь каждого, наполнит сердца всех граждан («Большевик должен иметь пустое сердце, чтобы туда все могло поместиться» [Платонов 2018а: 56]), и освободит всех, как кажется, даже от смерти. Бердяев так разъясняет суть русского социализма:

Вопрос о русском социализме - апокалиптический вопрос, обращенный к всеразрушающему концу истории. Русский революционный социализм никогда не мыслится, как относительное переходное состояние в социальном процессе, как временная форма экономического и политического устроения общества. Он мыслится всегда, как окончательное и абсолютное состояние, как решение судеб человечества, как наступление царства Божьего на земле (Бердяев 1923: 139).

Массовое убийство, таким образом, знаменует наступление коммунистического «царства» в Чевенгуре, но это кратковременная победа, поскольку внезапно появляется уже упоминавшийся отряд казаков, вполне возможно, направленный из главного управления коммунистической партии, который уничтожит всех жителей поселения.

После истребления буржуазии и полной победы коммунизма, смерть от болезни ребенка нищенки возбудило в Копенкине и некоторых других жителях Чевенгура сомнение, действительно ли был установлен коммунизм или это было всего лишь чистое социальное условие. Самого Чепурного мучает совесть, и он спрашивает себя, не умер ли ребенок именно из-за коммунизма. Тем не менее, ему удается найти множество оправданий в защиту своих действий по устройству нового коммунистического общества, и мать ребенка очень быстро понимает, с кем она имеет дело, как явствует из ее ответа: «- Нет, — сказала она, — тебе не мой ребенок дорог, тебе твоя дума нужна!» (Платонов 2018а: 271). Коммунистическая идея, в отличие от религиозной, которую она должна была заменить, не только не была в состоянии обещать чудеса, но даже и не была ясно понята жите- 
лями Чевенгура, для которых коммунизм был просто «обоюдное чувство масс» (Платонов 2018а: 241). Копенкин тем не менее, чувствовал «тихий коммунизм теплым покоем по всему телу, но не как личную высшую идею, уединенную в маленьком тревожном месте груди» (Платонов 2018а: 260). Неимущим жителям Чевенгура более естественным казалось восприятие коммунизма не как великой идеи, но, следуя совету Копенкина, они спускали «себе коммунизм из идеи в тело» (Платонов 2018а: 185), и он таким образом обретал простую форму чувства и восприятия.

Роман завершается двумя массовыми убийствами и самоубийством Дванова. Другие писатели-современники Платонова, Михаил Булгаков и Борис Пастернак, видели в революции апокалипсис. В Чевенгуре, однако, мы попадаем во время сразу после революции, время становления коммунистического общества, которое и было целью революции. Тем не менее, новая, светлая утопия живет под знаком Смерти, обнаруживая таким образом истинный смысл слова «утопия»: ои̉ «не»е то́лоऽ «место», т. е. «не-место», которое заслуживает того, чтобы быть стертым со скрижалей истории более коммунистическими коммунистами, чем жители Чевенгура.

\section{ЛИТЕРАТУРА}

Андреев Леонид. «К звездам». Андреев Леонид. Полное собрание сочинений. Т. 3. Санкт-Петербург: Изд. Т-ва А. Ф. Маркс, 1913.

Бальмонт Константин. «Будем как Солнце». Бальмонт Константин. Избранное. Стихотворения, Переводы, Статьи. Москва: Художественная литература, 1980.

Бердяев Николай. Миросозериание Достоевского. Прага: The Ymca Press Ltd., 1923.

Бердяев Николай. «Религия воскрешения». Бердяев Николай. Собрание сочинений. Т. III. Париж: Ymca Press, 1989.

Бердяев Николай. Русская идея. Санкт-Петербург: Азбука, 2015.

Бродский Иосиф. «Предисловие». Платонов Андрей. Котлован. Анн-Арбор: Ardis, 1973.

Вьюгин Валерий. Андрей Платонов: поэтика загадки. Санкт-Петербург: Изд-во Русского Христианского Гуманитарного Института, 2004.

Геллер Михаил. Андрей Платонов в поисках счастья. Москва: Изд-во «МИК», 1999.

Дмитровская Мария. «Антропологическая доминанта в этике и гносеологии А. Платонова (конец 20-х - середина 30-х годов)». Корниенко Наталья (ред.-сост.). «Страна философов» Андрея Платонова: проблемы творчества. Вып. 2. Москва: Наследие, 1995.

Дмитровская Мария. Макрокосм и микрокосм в художественном мире А. Платонова. Калининград: Изд-во КГУ, 1998.

Дооге Бен. «Мыслительные процессы и картины мира автора». Корниенко Наталья (ред.сост.). «Страна философов» Андрея Платонова: проблемы творчества. Вып. 6. Москва: ИМЛИ РАН, 2005.

Дооге Бен. Творческое преобразование языка и авторская концептуализация мира у А. П. Платонова. Опыт лингвопоэтического исследования языка романов Чевенгур u Счастливая Москва $и$ повести Котлован. Gent: Universiteit Gent, 2007.

Иванов Вячеслав Ив. «Хвала солнцу». Иванов Вячеслав Ив. Собрание сочинений. Т. 2. Брюссель: Foyer Oriental Chrétien, 1974.

Кубо Хисако. «Сектантские мотивы в Чевенгуре Андрея Платонова». Acta Slavica Iaponica 15 (1997).

Ленин Владимир. «О голоде. Письмо к питерским рабочим». Ленин Владимир. Полное собрание сочинений. Т. 36. Москва: Изд-во Полит. Литературы, 19745.

Маркс Карл. «Критика Готской программы. Замечания к программе германской рабочей партии». Маркс, Карл и Энгельс, Фридрих. Сочинения. Т. 19. Москва: Гос. Изд-во Политической Литературы, $1961^{2}$. 
Маяковский Владимир. «Необычайное приключение, бывшее с Владимиром Маяковским летом на даче». Маяковский Владимир. Полное собрание произведений. Т. 1. Москва: Наука, 2013.

Меерсон Ольга. Апокалипсис в быту. Поэтика неостранения у Андрея Платонова. Москва: Гранат, 2016.

Михеев Михаил. Андрей Платонов ... и другие. Языки русской литературы ХХ века. Москва: Языки Славянской Культуры, 2015.

Парамонов Борис. «Чевенгур и окрестности». Континент 54 (1987).

Платонов Андрей. «Джан». Платонов Андрей. Государственный житель. Проза, Ранние сочинения, Письма. Москва: Советский писатель, 1988.

Платонов Андрей. «Чевенгур». Платонов Андрей. Малое собрание сочинений. Санкт-Петербург: Азбука, 2018а.

Платонов Андрей. «Котлован». Платонов Андрей. Малое собрание сочинений. Санкт-Петербург: Азбука, $2018 б$.

Розанов Василий. «Опавшие листья. Короб первый». Розанов Василий. Избранное. Мюнхен: А. Нейманис, 1970а.

Розанов Василий. «Апокалипсис нашего времени». Розанов Василий. Избранное. Мюнхен: А. Нейманис, $1970 б$.

Семенова Светлана. «Философия воскрешения Н. Ф. Федорова». Федоров, Николай. Сoбрание сочинений: $B 4$ m. Т. 1. Москва: Издательская группа «Прогресс», 1995.

Толстая-Сегал Елена. «Идеологические контексты Платонова». Корниенко Наталья, Шубина Елена (сост.). Андрей Платонов: мир творчества. Москва: Современный писатель, 1994.

Федоров Николай. «Из первого тома “Философии общего дела”». Федоров Николай. Сочинения. Москва: Изд-во «Мысль», 1982.

Федоров Николай. «Будущее астрономии». Федоров Николай. Собрание сочинений: $B 4$ т. Т. 2. Москва: Издательская группа «Прогресс», 1995.

Чистов Кирилл. Русские народные сочиально-утопические легенды XVII-XIX вв. Москва: Наука, 1967.

Эпштейн Марк. «Язык бытия у Андрея Платонова». Bопросы литературы 3 (2006).

Эткинд Александр. Хльсст. Секты, литература и революиия. Москва: Новое литературное обозрение, 2019.

Яблоков Евгений. «О философской позиции А. Платонова (Проза середины $20-\mathrm{x}$ - начала 30-х годов)». Russian Literature XXXII/III (1992).

Яблоков Евгений. «Солнце». На берегу неба (Роман Андрея Платонова Чевенгур). СанктПетербург: Дмитрий Буланин, 2001.

Bethea David. The Shape of Apocalypse in Modern Russian Fiction. Princeton, New Jersey: Princeton University Press, 1989.

Brodskij Iosif. "Catastrofi nell'aria". Il canto del pendolo. Milano: Adelphi, 1987.

Borenstein Eliot. Men without Women. Masculinity and Revolution in Russian Fiction 1917-1929. Durham [N.C.]: Duke University Press, 2000.

Catteau Jacques. «De la métaphorique des utopies dans la littérature russe et de son traitement chez Andrej Platonov». Revue des études slaves 56/1 (1984).

Günther Hans. «Чевенгур и 'опоньское' царство. К вопросу народного хилиазма в романе А. Платонова». Russian Literature XXXII/ III (1992).

Lane Tora. Andrey Platonov. The Forgotten Dream of the Revolution. Lanham [etc.]: Lexington Books, 2018.

Livingstone Angela. «Half-Worlds and Horizons in Platonov's Chevengur». Slavonica IX/2 (2003).

Seifrid Thomas. Andrei Platonov: Uncertainties of Spirit. Cambridge [etc.]: Cambridge University Press, 1992.

\section{LITERATURE}

Andreev Leonid. «K zvezdam». Andreev Leonid. Polnoe sobranie sochinenij. T. 3. Sankt-Peterburg: Izd. T-va A. F. Marks, 1913.

Bal'mont Konstantin. «Budem kak Solnce». Bal'mont Konstantin. Izbrannoe. Stihotvoreniya, Perevody, Stat'i. Moskva: Hudozhestvennaya Literatura, 1980. 
Berdyaev Nikolaj. Mirosozercanie Dostoevskogo. Praga: The Ymca Press Ltd., 1923.

Berdyaev Nikolaj. «Religiya voskresheniya». Berdyaev Nikolaj. Sobranie sochinenij. T. III. Parizh: Ymca Press, 1989.

Berdyaev Nikolaj. Russkaya ideya. Sankt-Peterburg: Azbuka, 2015.

Bethea David. The Shape of Apocalypse in Modern Russian Fiction. Princeton, New Jersey: Princeton University Press, 1989.

Brodskij Iosif. "Catastrofi nell'aria". Brodskij Iosif. Il canto del pendolo. Milano: Adelphi, 1987.

Brodskij Iosif. «Predislovie». Platonov, Andrej. Kotlovan. Ann-Arbor: Ardis, 1973.

Borenstein Eliot. Men without Women. Masculinity and Revolution in Russian Fiction 1917-1929.

Durham [N.C.]: Duke University Press, 2000.

Catteau Jacques. «De la métaphorique des utopies dans la littérature russe et de son traitement chez Andrej Platonov». Revue des études slaves 56/1 (1984).

Chistov Kirill. Russkie narodnye social'no-utopicheskie legendy XVII-XIX vv. Moskva: Nauka, 1967.

Dmitrovskaya Mariya. «Antropologicheskaya dominanta v etike i gnoseologii A. Platonova (konec 20-h — seredina 30-h godov)». Kornienko Natal'ya (red.-sost.). «Strana filosofov» Andreya Platonova: problemy tvorchestva. Vyp. 2. Moskva: Nasledie, 1995.

Dmitrovskaya Mariya. Makrokosm i mikrokosm v hudozhestvennom mire A. Platonova. Kaliningrad: Izd-vo KGU, 1998.

Dooge Ben. «Myslitel'nye processy i kartiny mira avtora». Kornienko Natal'ya (red.-sost.). «Strana filosofov» Andreya Platonova: problemy tvorchestva. Vyp. 6. Moskva: IMLI RAN, 2005.

Dooge Ben. Tvorcheskoe preobrazovanie yazyka i avtorskaya konceptualizaciya mira u A. P. Platonova. Opyt lingvopoeticheskogo issledovaniya yazyka romanov Chevengur $i$ Schastlivaya Moskva i povesti Kotlovan. Gent: Universiteit Gent, 2007.

Epshtejn Mark. «Yazyk bytiya u Andreya Platonova». Voprosy literatury 3 (2006).

Etkind Aleksandr. Hlyst. Sekty, literatura i revolyuciya. Moskva: Novoe literaturnoe obozrenie, 2019.

Fedorov Nikolaj. «Iz pervogo toma "Filosofii obshchego dela"». Fedorov Nikolaj. Sochineniya. Moskva: Izd-vo «Mysl'», 1982.

Fedorov Nikolaj. «Budushchee astronomii». Fedorov Nikolaj. Sobranie sochinenij: V 4 t. T. 2. Moskva: Izdatel'skaya gruppa «Progress», 1995.

Geller Mihail. Andrej Platonov v poiskah schast'ya. Moskva: Izd-vo «MIK», 1999.

Günther Hans. «Chevengur i 'opon'skoe' carstvo. K voprosy narodnogo hiliazma v romane A. Platonova». Russian Literature XXXII/III (1992).

Ivanov Vyacheslav Iv. «Hvala solncu». Ivanov Vyacheslav Iv. Sobranie sochinenij. T. 2. Bryussel’: Foyer Oriental Chrétien, 1974.

Kubo Hisako. «Sektantskie motivy v Chevengure Andreya Platonova». Acta Slavica Iaponica 15 (1997).

Lane Tora. Andrey Platonov. The Forgotten Dream of the Revolution. Lanham [etc.]: Lexington Books, 2018.

Lenin Vladimir. "O golode. Pis'mo k piterskim rabochim». Lenin Vladimir. Polnoe sobranie sochinenij. T. 36. Moskva: Izd-vo Politicheskoj Literatury, 1974.

Livingstone Angela. «Half-Worlds and Horizons in Platonov's Chevengur». Slavonica IX/2 (2003).

Marks Karl. «Kritika Gotskoj programmy. Zamechaniya k programme germanskoj rabochej partii». Marks, Karl i Engel's, Fridrih. Sochineniya. T. 19. Moskva: Gos. Izd-vo Politicheskoj Literatury, $1961^{2}$.

Mayakovskij Vladimir. «Neobychajnoe priklyuchenie, byvshee s Vladimirom Mayakovskim letom na dache». Mayakovskij Vladimir. Polnoe sobranie proizvedenij. T. 1. Moskva: Nauka, 2013.

Meerson Ol'ga. Apokalipsis v bytu. Poetika neostraneniya u Andreya Platonova. Moskva: Granat, 2016.

Miheev Mihail. Andrej Platonov ... i drugie. Yazyki russkoj literatury XX veka. Moskva: Yazyki Slavyanskoj Kul'tury, 2015.

Paramonov Boris. «Chevengur i okrestnosti». Kontinent 54 (1987).

Platonov Andrej. «Dzhan». Platonov Andrej. Gosudarstvennyj zhitel’. Proza, Rannie sochineniya, Pis'ma. Moskva: Sovetskij pisatel', 1988. 
Platonov Andrej. «Chevengur». Platonov Andrej. Maloe sobranie sochinenij. Sankt-Peterburg: Azbuka, 2018a.

Platonov Andrej. «Kotlovan». Platonov Andrej. Maloe sobranie sochinenij. Sankt-Peterburg: Azbuka, 2018b.

Rozanov Vasilij. «Opavshie list’ya. Korob pervyj». Rozanov Vasilij. Izbrannoe. Myunhen: A. Nejmanis, 1970a.

Rozanov Vasilij. «Apokalipsis nashego vremeni». Rozanov Vasilij. Izbrannoe. Myunhen: A. Nejmanis, 1970b.

Seifrid Thomas. Andrei Platonov: Uncertainties of Spirit. Cambridge [etc.]: Cambridge University Press, 1992.

Semenova Svetlana. «Filosofiya voskresheniya N. F. Fedorova». Fedorov, Nikolaj. Sobranie sochinenij: V 4 t. T. 1. Moskva: Izdatel'skaya gruppa «Progress», 1995.

Tolstaya-Segal Elena. «Ideologicheskie konteksty Platonova». Kornienko Natal'ya, Shubina Elena (sost.). Andrej Platonov: mir tvorchestva. Moskva: Sovremennyj pisatel', 1994.

V'yugin Valerij. Andrej Platonov: poetika zagadki. Sankt-Peterburg: Izd-vo Russkogo Hristianskogo Gumanitarnogo Instituta, 2004.

Yablokov Evgenij. «O filosofskoj pozicii A. Platonova (Proza serediny 20 -h - nachala $30-\mathrm{h}$ godov)». Russian Literature. XXXII/ III (1992).

Yablokov Evgenij. «Solnce». Yablokov Evgenij. Na beregu neba (Roman Andreya Platonova Chevengur). Sankt-Peterburg: Dmitrij Bulanin, 2001.

Луиђи Магарото

ТРАГИЧКА РЕШЕЊА У РОМАНУ ЧЕВЕНГУР АНДРЕЈА ПЛАТОНОВА

Резиме

Аутор анализира главне теме које чине структуру романа Чевенг̄ур Андреја Платонова. Пре свега, он се задржава на пишчевом начину излагања, који збуњује читаоца презасићеношћу различитим техникама и својом фрагментираношћу. Затим се испитује утицај теорије о васкрсењу мртвих, коју је развио Николај Фјодоров. У даљем раду аутор показује да одсуство жена у Чевенгуру неизоставно доводи мушку популацију до манифестација хомосексуалности. Чини се да комунизам створен у Чевенгуру није вођен Лењиновим заповестима, већ идејама бројних мистично-религијских секти, које се у руској историји срећу у изобиљу. Рад се укида не због победе комунизма, већ зато што постоји сунце, које својом снагом и топлотом становницима бесконачне степе дарује све што им је потребно за живот. Трагичка одлика чевенгурског комунизма јесте истребљење свих буржуја, припадника насеобине, у име успостављања правог комунистичког система. Штавише, масовно убиство је такође дефинисано као други долазак, у покушају да се на овај начин повуче паралела између комунистичког друштва на земљи и раја на небу: то су, наводно, два места, где живе праведници.

Кључне речи: Чевенг̄yp, Андреј Платонов, васкрсење мртвих, сексуални односи, праведност, социјал-комунистички рад, рајско комунистичко друштво. 